\title{
Intercultural education in the primary school education in Romania: ways to achieve and integrate it in curricular documents. Students' \\ perspective
}

\section{Dorin OPRIŞ*,}

\begin{abstract}
Intercultural education is unanimously recognized as one of the new dimensions of education. In Romania, in the 6th grade, students aged 12-13 years study a subject with this name, according to the curricular documents entered into force in 2017. At the same time, in various other subjects, especially from the socio-human area, numerous elements of interculturality are found in each educational cycle. Because in the primary school education it lays the foundations of the later stages of formal education and personal development of the students, we were interested to see the support that this new dimension of this type of education benefits in the school curriculum from Romania. The results indicate a strong support for intercultural education from school subjects such as Religion, Personal Development, Social Education. This article includes the results of a research we conducted with the help of the survey based on a questionnaire, to identify how the students from the bachelor's degree specialization "Pedagogy of primary and pre-school education" relate to the possible ways of achieving and integrating the intercultural education in curricular documents at the primary school education. We wanted to identify the point of view of the students, the future teachers from primary school education, which is why the research was carried out at the end of the last year of their undergraduate studies. The conclusions show that there is a certain knowledge of the problem of the intercultural education at the primary school education, based on the university studies and the experience in the classroom, from the teaching practice or from the current activity of the students already working in education. However, we cannot fail to notice the significant differences between the points of view of those who have experience in teaching activity, including during high school education in a pedagogical high school, compared to their colleagues who have a much lower didactic experience.
\end{abstract}

Keywords: primary school education, interculturality, teaching experience, university studies, teaching practice of students.

\footnotetext{
- Associate Professor, PhD., Prof. habil. „The1st December of 1918”University from Alba Iulia, DPPD, e-mail: dorin monica@yahoo.com
} 


\section{Preliminaries}

The issue of intercultural education has also become in Romania for more than two decades a constant presence in the debates in the educational area and not only, because of the increasing challenges related to cultural exchanges and intercultural meetings that benefit students, but Romanian students. At the same time, the accelerated globalization, with population exchanges between countries and continents, a process of unprecedented magnitude in the last centuries, in which Romania is also a part, makes the attention of the investigative efforts in the field of education sciences to be increasingly directed towards this area.

The research undertaken by us had a sample of 100 students in the third year in the specialization "Pedagogy of primary and pre-school education" (PIPP), from the form of day courses and from distance courses, before their graduating. We chose this sample due to the fact that in the university curricula it is foreseen to study Intercultural education in the IIIrd year. Thus, we add to the experience that many of them have as teachers in the Romanian pre-university education, the one from the teaching practice in the primary school education, realized during the three years of the degree studies, under the coordination of a university teacher and of a mentor from the application school where this teaching practice is carried out. Our previous research has shown us that the end of the bachelor's degree is the most appropriate moment for a pedagogical research, since the meeting with the elements of interculturality and the challenges that they raise in the educational space knows a significant moment. The sample of subjects was established by the method of the sampling step, after eliminating the questionnaires in which the requested data were presented incorrectly.

\section{Characterization of the sample of subjects and data analysis}

$18 \%$ of the sample of subjects are graduates of the teaching high school, and $82 \%$ of them graduated a high school with a different specialization. Almost half of the respondents $(40 \%)$ enrolled in the college immediately after finishing high school, and the others $(60 \%)$ at a number of years. Regarding the age distribution, we have three levels: $56 \%$ are between the ages of $20-29$ years, $32 \%$ between $30-39$ years and $12 \%$ between 40-49 years.

In order to interpret the data, the job of the students plays an important role. Thus, $43 \%$ already work in education (based on teaching high school, as a result of undergraduate studies in other fields or are unskilled substitutes), 20\% in another field, and $37 \%$ do not work (in this case it is mainly respondents who started their university studies immediately after finishing high school). 
The students who have already worked in education have the following age brackets (out of a total of 43\%): 23\% between 1-5 years; $7 \%$ between $6-10$ years; $7 \%$ between $11-15$ years; $4 \%$ between $16-20$ years; $2 \%$ over 20 years.

In the sample of the present research, we have an insignificant percentage of students who declare that they have had significant experiences in the family regarding interculturality, so we do not have relevant data for the analysis according to such a variable. At the same time, we can consider that the opinions expressed in the research are based on the information acquired in the undergraduate studies, as well as on the experience as a teacher in pre-university education, respectively in the teaching practice activities.

The data in this article were analyzed in order to highlight the students' opinion regarding the values associated with intercultural education and the possibilities for its achievement in primary education in Romania. We did not consider the analysis of the research data relevant after the form of education - day courses/ frequency education, respectively distance courses/ID programs - as all students in the sample followed the same university curriculum and benefited from the same stages of teaching practice.

\section{Intercultural education and priorities from the pedagogical space of the students from "Pedagogy of primary and pre-school education" specialization}

One of the items in the questionnaire asked the students to give a grade from 1 to 10 ( 1 - the minimum value, 10 - the maximum value) to some aspects related to intercultural education, during the collegiate discussions that they participated during the university studies in within the framework of the degree program "Pedagogy of primary and pre-school education" (PIPP). In the list presented by us, we find different aspects for most dimensions of education, placed in a random order. In table 1, we presented the results in the order of the averages calculated based on the grades offered by the students.

According to the data in table 1, we observe that in the pedagogical discussions of the students in the first place are the aspects related to moral education, with an average of 9.30, the only average with values between 9-10. At 40 cents, there are aspects related to intercultural education (average $=8.94$ ). The students' discussions focus on issues related to moral, intercultural, civic and religious education, which scored above the average for the entire sample $(\mathrm{m}=8.40)$.

Even if it is unanimously recognized that the current Romanian education focuses on cognitive / informative aspects to a higher degree than on the formative component, in the discussions between the students from the PIPP, the elements in the university curriculum run by the students is implicitly present. 
Table 1 Topics of discussion among PIPP students, in relation to different areas of education, in descending order of the average

\begin{tabular}{|r|c|}
\hline Definitive aspects for different fields of education & Average \\
\hline 1. the need for moral education of children & 9,3 \\
\hline 2. carrying out an education that facilitates the integration of \\
minority groups in the majority groups & 8,9 \\
\hline 3. the importance of involving the students in the civic field & 8,6 \\
\hline 4. the role of religious education in shaping new generations & 8,5 \\
\hline $\begin{array}{l}\text { 5. the need for an ecological education adapted to the new } \\
\text { challenges of today's society }\end{array}$ & 8,4 \\
\hline $\begin{array}{l}\text { 6. the importance of a good technological education of the } \\
\text { children }\end{array}$ & 8,3 \\
\hline 7. the role of aesthetic / plastic education in the training and \\
development of the child
\end{tabular}

In the case of this item, for the aspects of interculturality we have performed analyzes according to different variables. We were particularly interested in the percentage of students who scored grades 9 and 10, namely values above the average obtained for the entire sample $(\mathrm{m}=8.90)$. Regarding the specialization of the high school the students followed, there are no significant differences between those who graduated from a teaching high school and those who graduated from another high school: $77.77 \%$ of the total students who graduated from teaching high school gave grades of 9 and 10, respectively $75.60 \%$ of the students who graduated from high school at another specialization.

If we report the results according to the job of the respondents, the research data reveal a lower percentage of grades of 9 and 10 for the elements of interculturality in the students already working in education (69.76\%), compared to those who work in another area (80\%), respectively those who do not work (81\%).

The analysis of the data according to the seniority in education highlights differences, more precisely a relationship of inverse proportionality between the percentage of high marks granted by the respondents and the number of years of seniority in education, as evidenced by the distribution curve of the results, in figure 1. 


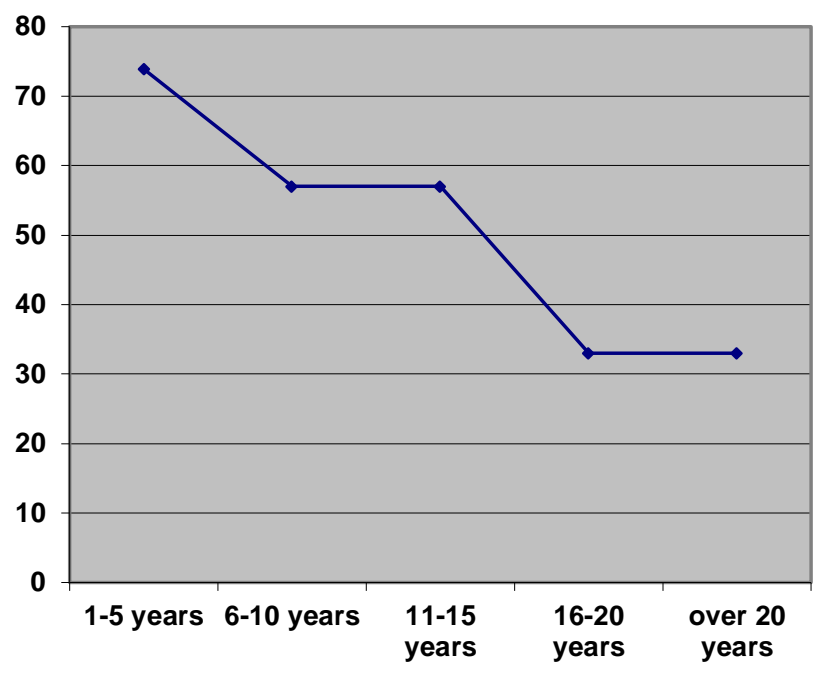

$\longrightarrow$ marks of 9 and 10

Fig.1. Distribution curve of the percentage of teachers who gave grades of 9 and 10 , according to seniority in education

It is thus highlighted that in the pedagogical discussions of the students from PIPP the topics related directly to the domains that consider personality formation take precedence. The elements of intercultural education are present mainly in the concerns of students working in other areas than the educational one or not working, in relation to those who are already teachers. Of the students who are already working in education, those with older seniority explicitly value less intercultural education than those with little seniority in education (1-5 years).

\section{The students from PIPP and the values of intercultural society}

Another item considered how students from PIPP relate personally to the principles and values of an intercultural society: developing their own cultural identity, accepting and respecting diversity, positive appreciation of differences, equal treatment of people, solidarity, promoting social inclusion, intercultural dialogue. We proposed three sets of two pair statements, one of which promotes openness to intercultural values (1.1., 2.2., 3.2.). The students were invited to choose from the list of six statements that characterize them most. The results are presented in table 2.

The data in table 2 reflect that, internally, students value the elements of interculturality in a high degree. Most elections (82.66\%) received statements regarding their own cultural identity and the need to positively value the differences: "I accept the idea that we are different constitutively" and "The knowledge and understanding of those around us is a complex and progressive process". It is the choice to refer social inclusion $(72 \%)$ at a statistically significant difference of more than 10 percentage points. 
Table 2 Reporting students on a personal level to the principles and values of an intercultural society

\begin{tabular}{|l|c|}
\hline \multicolumn{1}{|c|}{ Affirmations in the field of intercultural education } & $\begin{array}{c}\% \\
\text { choises }\end{array}$ \\
\hline 1.1. I accept the idea that we are different constitutively. & $\mathbf{8 9}$ \\
\hline 1.2. I think the groups should not keep their identity. & $\mathbf{1}$ \\
\hline $\begin{array}{l}\text { 2.1. It is necessary to standardize the value standards in today's } \\
\text { society. }\end{array}$ & $\mathbf{3 6}$ \\
\hline $\begin{array}{l}\text { 2.2. Knowing and understanding those around us is a complex and } \\
\text { progressive process. }\end{array}$ & $\mathbf{8 7}$ \\
\hline $\begin{array}{l}\text { 3.1. I hardly accept in my group those who do not have good relations } \\
\text { with all people. }\end{array}$ & $\mathbf{1 3}$ \\
\hline 3.2. I easily include those who are different from others in my group. & $\mathbf{7 2}$ \\
\hline
\end{tabular}

The highest percentage of students, almost a third, chose this statement from the statements that are not in favor of the values of an intercultural society: "It is necessary to standardize the value standards in today's society." Research data show that almost half of the students $(47 \%)$ chose at least one statement with negative connotations in relation to intercultural education, $4 \%$ of the total chose two such statements. No student made the three choices of statements with negative connotations.

\section{The educational priorities of students from PIPP, from the perspective of diversity reporting}

The presence in the class of students belonging to cultural, religious, ethnic area etc. different from those of the majority naturally raise a series of pedagogical questions from all the factors involved in the educational process: on the one hand, the teacher refers to a hidden curriculum, based on his own perception of the cultural difference present in the school space, and on the other hand it faces a reality (the students, but also the school environment as a whole) that forces it to adapt its teaching style to the individual and group particularities, respectively to the specific educational needs of the actors involved in the teaching process. In another plan, the challenges come on the one hand from the way the students in the majority group respect the values of the minority group, and on the other, from the way the students from the minority group receive the impact that their values have on them. These four different ways of reporting diversity, two from the teacher and two from the students, were the subject of another item. The respondents were invited to rank them according to the priorities that they consider 
should have their intercultural education in the school space (1st place - the least important, 4th place - the most important). The data are presented in table 3.

Table 3 Educational priorities from the perspective of the teacher and students

\begin{tabular}{|l|c|c|c|c|c|}
\hline $\begin{array}{c}\text { Methods of action for the } \\
\text { integration of students belonging } \\
\text { to cultural, religious, etc. different } \\
\text { from the majority }\end{array}$ & $\begin{array}{c}\mathbf{1 s t} \\
\text { plac } \\
\text { e }\end{array}$ & $\begin{array}{c}\mathbf{2 n d} \\
\text { plac } \\
\mathbf{e}\end{array}$ & $\begin{array}{c}\mathbf{3 r d} \\
\text { plac } \\
\mathbf{e}\end{array}$ & $\begin{array}{c}\mathbf{4 t h} \\
\text { Plac } \\
\mathbf{e}\end{array}$ & $\begin{array}{c}\text { Tot } \\
\text { al } \\
\mathbf{3 +} \\
\mathbf{4}\end{array}$ \\
\hline $\begin{array}{l}\text { how the teacher perceives the } \\
\text { cultural difference }\end{array}$ & 28 & 22 & 12 & $\mathbf{3 6}$ & 48 \\
\hline $\begin{array}{l}\text { how the teacher adapts his / her style } \\
\text { to the student's cultural profile }\end{array}$ & 19 & 25 & 36 & $\mathbf{2 0}$ & 56 \\
\hline Total teacher & $\mathbf{4 7}$ & $\mathbf{4 7}$ & $\mathbf{4 8}$ & $\mathbf{5 6}$ & \\
\hline $\begin{array}{l}\text { how the student in a minority group } \\
\text { receives the values of the majority }\end{array}$ & 19 & 32 & 29 & $\mathbf{2 0}$ & 49 \\
\hline $\begin{array}{l}\text { how the students in the majority } \\
\text { group respect the cultural values of } \\
\text { the students in the minority group }\end{array}$ & 34 & 21 & 23 & $\mathbf{2 2}$ & 45 \\
\hline Total students & $\mathbf{5 3}$ & $\mathbf{5 3}$ & $\mathbf{5 2}$ & $\mathbf{4 4}$ & \\
\hline
\end{tabular}

The data in table 3 show a certain balance in terms of the respondents' image of the pedagogical actions included in the item. The biggest differences appear for the actions placed on the 4 th place, considered to be the most important by respondents. Thus, 56\% of the respondents place the responsibility on the teacher, especially regarding the need to change their mentality regarding cultural, religious and ethnic differences. We find at a difference of 12 percentage points the answers of those who consider that more important than the actions of the teacher are those regarding the relationships between students, both in the case of the majority group $(22 \%)$ and those of the minority group (20\%).

\section{Values of intercultural education and curricular documents from the primary school education}

From the analysis of the school curriculum in use for the primary and secondary school (which includes pupils between the ages of 6-15 years), we observe that, with the exception of the 6th grade where the Intercultural education appears as a self-discipline within Social education subject, in all the other classes, a number of elements of interculturality appear, in different forms, at the level of education purposes, learning contents, examples of learning activities. 
Two of the eight key-competences supported by the educational policies at European level ${ }^{3}$ : "interpersonal, intercultural, social and civic competences" and "cultural sensitivity" are supported by most disciplines in the curricular area "Human and society". For example, in Table 4, we present the way in which different elements of interculturality are formulated or presented at the level of contents of the learning in the primary cycle in the school curriculum of some school subjects.

Table 4 Elements of interculturality, approached at the content level in the study of some school subjects

\begin{tabular}{|c|c|c|}
\hline Subject & Grade & $\begin{array}{l}\text { Examples of learning contents in which } \\
\text { elements of interculturality can be approach }\end{array}$ \\
\hline R.E. (Religious Education) & $\mathrm{P}$ & $\begin{array}{l}\text { God is teaching us to help one another } \\
\text { - I am a Christian at school, too (relationship with } \\
\text { adults and children at school) } \\
\text { - My first friends (colleagues and friends; } \\
\text { choosing friends; friendship models, etc.) } \\
\text { - People from all over the world (diversity of } \\
\text { people in the world; activities for helping others, } \\
\text { etc.) }\end{array}$ \\
\hline $\begin{array}{l}\text { Personal } \\
\text { Development }\end{array}$ & $\mathrm{P}$ & $\begin{array}{l}\text { Simple interactions with familiar beings and } \\
\text { objects }{ }^{5} \\
\text { - Favourite beings and objects. Their } \\
\text { characteristics }\end{array}$ \\
\hline R.E. (Religious Education) & $\begin{array}{l}\text { Ist } \\
\text { Grade }\end{array}$ & $\begin{array}{l}\text { Man prays to God for himself and others }{ }^{6} \\
\text { - For whom I pray (prayer for all people) } \\
\text { - The benefits of prayer (strengthening the } \\
\text { relationship between people) }\end{array}$ \\
\hline $\begin{array}{l}\text { Personal } \\
\text { Development }\end{array}$ & $\begin{array}{l}\text { Ist } \\
\text { Grade }\end{array}$ & $\begin{array}{l}\text { Simple interactions with familiar beings and } \\
\text { objects }^{7}\end{array}$ \\
\hline
\end{tabular}

\footnotetext{
${ }^{3}$ Irina Horga, "Religious Education - an explicit choice of European education systems", in Dorin Opriş (coordinator), Religious education in dialogue with society. Pedagogical, psychological and historical research, Alba Iulia, Reintegirea Publishing House

4 ***Syllabus for Religious Education school subject, Orthodox worship, Preparatory grade, the Ist grade and the IInd grade, approved by the order of the minister of National Education, no. 3418/ 19.03.2013, pp. 10-11.

5 *** Syllabus for Personal Development school subject, Preparatory grade, the Ist grade and the IInd grade, approved by the order of the minister of National Education, no. 3418/19.03.2013, p. 10.

$6 * * *$ Syllabus for Religious Education school subject, Orthodox worship, Preparatory grade, the Ist grade and the IInd grade.., pp. 10-11.

7 *** Syllabus for Personal Development school subject, Preparatory grade, the Ist grade and the IInd grade..., p. 10.
} 


\begin{tabular}{|c|c|c|}
\hline & & $\begin{array}{l}\text { - The friendship. The main characteristics of a } \\
\text { good friend. What is a good friend? }\end{array}$ \\
\hline R.E. (Religious Education) & $\begin{array}{l}\text { the } \\
\text { IInd } \\
\text { grade }\end{array}$ & $\begin{array}{l}\text { People show their love for one another } 8 \\
\text { - Gratitude towards those who do us good (what } \\
\text { is gratitude; biblical examples of people who have } \\
\text { shown their gratitude to benefactors; models in } \\
\text { the daily life of rewarding those who do us good, } \\
\text { etc.) }\end{array}$ \\
\hline $\begin{array}{l}\text { Personal } \\
\text { Development }\end{array}$ & $\begin{array}{l}\text { the } \\
\text { IInd } \\
\text { grade }\end{array}$ & $\begin{array}{l}\text { Simple interactions with familiar beings and } \\
\text { objects } 9 \\
\text { - Necessary skills and accepted behaviors in } \\
\text { relationships with others Respect in relationships } \\
\text { with others }\end{array}$ \\
\hline R.E. (Religious Education) & $\begin{array}{l}\text { the } \\
\text { IIIrd } \\
\text { grade }\end{array}$ & $\begin{array}{l}\text { Life with others } 10 \\
\text { - Gentleness and kindness in relation to others } \\
\text { - Respect for self and others }\end{array}$ \\
\hline $\begin{array}{l}\text { Civic } \\
\text { Education }\end{array}$ & $\begin{array}{l}\text { the } \\
\text { IIIrd } \\
\text { grade }\end{array}$ & $\begin{array}{l}\text { The concept of person }{ }^{11} \\
\text { - What does it mean to be people? } \\
\text { - My person } \\
\text { - His/Her person } \\
\text { Our relationships with other people } \\
\text { - Small groups of which we belong (family, friends } \\
\text { group, play group, learning group) and the } \\
\text { relationships between their members }\end{array}$ \\
\hline R.E. (Religious Education) & $\begin{array}{l}\text { the } \\
\text { IVth } \\
\text { grade }\end{array}$ & $\begin{array}{l}\text { Christian love, support for living with others } 12 \\
\text { - Love, command given by the Lord Jesus Christ } \\
\text { - Life in harmony with others, an urge of God } \\
\text { - The friendship and the command of christian } \\
\text { love }\end{array}$ \\
\hline Civic Education & $\begin{array}{l}\text { the } \\
\text { IVth } \\
\text { grade }\end{array}$ & $\begin{array}{l}\text { Local membership } 13 \\
\text { - Local traditions } \\
\text { National membership }\end{array}$ \\
\hline
\end{tabular}

\footnotetext{
8 *** Syllabus for Religious Education school subject, Orthodox worship, Preparatory grade, the Ist grade and the IInd grade..., p.10

9 *** Syllabus for Personal Development school subject, Preparatory grade, the Ist grade and the IInd grade..., p. 10.

10 *** Syllabus for Religious Education school subject, Orthodox worship, the 3rd and the 4th grade, approved by the order of the minister of National Education, no. 5001/ 02.12.2014, p. 8.

11 *** Syllabus for Civic Education school subject, the 3rd and the 4th grade, approved by the order of the minister of National Education, no. 5003/ 02.12.2014, pp. 10-11

12 *** Syllabus for Religious Education school subject, Orthodox worship, the 3rd and the 4th grade..., p. 8..

13 *** Syllabus for Civic Education school subject, the 3rd and the 4th grade..., pp. 10-11.
} 


\begin{tabular}{|l|l|}
\hline & $\begin{array}{l}\text { - Homeland and, where appropriate, country } \\
\text { where we live } \\
\text { Moral-civic behavior } \\
\text { - daily moral life: family behavior; behavior in } \\
\text { school; behavior in the group of friends; behavior } \\
\text { in public places } \\
\text { - prosocial behaviors (help, cooperation, } \\
\text { competition, tolerance, support, volunteering) } \\
\text { and antisocial (conflictual, aggressive) }\end{array}$ \\
\hline
\end{tabular}

Starting from the data from the preliminary research, presented in table 4, we proposed an item by which we wanted to find out the status that the students would grant to the intercultural education in the curricular documents for the primary education. We formulated a semi-open item, in which, in addition to the three variants proposed by us, we also introduced an open item in which I gave the respondents the possibility to specify another variant. The data obtained are presented in table 5 .

Table 5 Ways of integrating the elements of intercultural education in the curriculum at the primary school education, related to the total sample

\begin{tabular}{|l|c|}
\hline $\begin{array}{l}\text { Ways of integrating intercultural education in curricular } \\
\text { documents from the primary school education }\end{array}$ & $\begin{array}{c}\text { Total } \\
\text { choises } \\
\text { (\%) }\end{array}$ \\
\hline 1. It should be introduce a school subject, in its own right. & 52 \\
\hline $\begin{array}{l}\text { 2. Elements of intercultural education should be included in the } \\
\text { curriculum of some school subjects. }\end{array}$ & 29 \\
\hline $\begin{array}{l}\text { 3. Learning activities should be carried out only when situations } \\
\text { involving elements of interculturality arise. }\end{array}$ & 17 \\
\hline 4. Other way: optional. & 2 \\
\hline Total (\%) & 100 \\
\hline
\end{tabular}

Over half of the respondents (52\%) opted for the alternative of a school subject, in its own right. Almost half (48\%) being divided between the introduction of elements of intercultural education in the curriculum of some educational disciplines, as it is now realized (29\%), carrying out learning activities for specific situations (17\%), respectively the introduction of an optional discipline (2\%).

The percentages regarding the possibilities of integrating the elements of intercultural education in the curriculum at the primary school, depending on the type of high school graduates (pedagogical or other high school) by the respondents, are presented in table 6 . 
Table 6 Ways of integrating the elements of intercultural education in the curriculum at the primary school subject, depending on the type of high school graduates

\begin{tabular}{|c|c|c|}
\hline \multirow{2}{*}{$\begin{array}{l}\text { Ways of integrating intercultural education in } \\
\text { curricular documents from the primary school } \\
\text { education }\end{array}$} & \multicolumn{2}{|c|}{$\begin{array}{c}\text { The type of high } \\
\text { school graduate }(\%)\end{array}$} \\
\hline & $\begin{array}{l}\text { Teaching } \\
\text { high } \\
\text { school }\end{array}$ & $\begin{array}{l}\text { Another } \\
\text { high } \\
\text { school }\end{array}$ \\
\hline 1. It should be introduced a school subject, in its own right. & 44 & 53,7 \\
\hline $\begin{array}{l}\text { 2. Elements of intercultural education should be included } \\
\text { in the curriculum of some school subjects. }\end{array}$ & 44 & 25,6 \\
\hline $\begin{array}{l}\text { 3. Learning activities should be carried out only when } \\
\text { situations involving elements of interculturality arise. }\end{array}$ & 12 & 18,3 \\
\hline 4. Other way: optional. & 0 & 2,4 \\
\hline Total (\%) & 100 & 100 \\
\hline
\end{tabular}

The data analysis shows for the first variant a lower percentage with almost ten percentage points for graduate students of teaching high school. A greater positive difference regarding the teaching high school graduates, of almost 20 percentage points, compared to the total of the choises, appears for the second variant. We find identical percentage values for the first two variants of integration of the elements of intercultural education in the case of graduate students of pedagogical high school (44\%). A statistically significant increase appears at variant no. 3, for graduates from a high school other than the pedagogical one, which proposes that the elements of interdisciplinarity be introduced to the primary cycle when educational situations arise that demand these measures. The research data indicate a strong polarization of the options of the teaching high school graduates towards the constant approach of the elements of intercultural education at the primary cycle, corresponding to the first two possibilities of integrating it. A much lower knowledge of the school realities made the graduates of another high school than the teaching one, for whom the professional experience in the primary education was summarized until the moment of the research in the pedagogical practice of the three years of college, led to the strong option for the first variant of integrating intercultural education into the primary cycle.

Another analysis of the data was made according to the students' workplace. We have reported the data for the total number of students for each of the three categories: who work in education (table 7). 
Table 7 Ways of integrating the elements of intercultural education in the curriculum at the primary school education, according to the job of the respondents

\begin{tabular}{|l|c|c|c|}
\hline & \multicolumn{3}{|c|}{ The place of work: } \\
$\begin{array}{l}\text { Ways of integrating intercultural } \\
\text { education in curricular documents from } \\
\text { the primary school education }\end{array}$ & $\begin{array}{c}\text { education } \\
(43 \%)\end{array}$ & $\begin{array}{c}\text { other } \\
\text { area } \\
(20 \%)\end{array}$ & $\begin{array}{c}\text { not work } \\
(37 \%)\end{array}$ \\
\hline $\begin{array}{l}\text { 1. It should be introduce a school subject, in } \\
\text { its own right. }\end{array}$ & 48,8 & 50 & 56,7 \\
\hline $\begin{array}{l}\text { 2. Elements of intercultural education } \\
\text { should be included in the curriculum of } \\
\text { some school subjects. }\end{array}$ & 30,23 & 40 & 27,1 \\
\hline $\begin{array}{l}\text { 3. Learning activities should be carried out } \\
\text { only when situations involving elements of } \\
\text { intercultural arise. }\end{array}$ & 16,37 & 10 & 16,2 \\
\hline $\begin{array}{l}\text { 4. Other way: optional. } \\
\text { Total (\%) }\end{array}$ & 4,6 & 0 & 0 \\
\hline
\end{tabular}

Research data shows that, $48.8 \%$ of the respondent students who were already enrolled in education at the time of this research believe that intercultural education should be supported in the primary school education by a school subject, in its own right. The other half proposes other ways of integrating the elements of interculturality into the curriculum. The value of the amplitude in the case of those who propose a new discipline is almost 8 percentage points, the highest value being registered for students who did not have a job at the moment. In the case of those who propose to support the elements of intercultural education through the contribution of several school subjects, the highest percentage values appear in those who work in another field than the education $(40 \%)$, the value of the amplitude being $\mathrm{A}=12.9$.

\section{Conclusions}

Students who already have the experience of integrating elements of interculturality at the level of other educational disciplines, especially in "Personal Development" and "Civic Education", operate more openly with the terms. At the same time, the novelty and the challenges involved in the achievement of intercultural education, make the students with less experience in education consider that a selfdiscipline is required to sustain in the Romanian primary education the values of this new dimension of education. 
A strong element of support for an effective achievement of intercultural education in the current Romanian primary school education may be constituted by a better presentation within the university curriculum of the values of this dimension of education, present in the school curricula of different disciplines. We refer here in particular to the exercise of reading and understanding by the students of the curricular documents by "reading in integrum" of the curricula at the level of the primary school education, so that the distinction between the school subjects is not supported only by the formulation of the contents of learning.

The data of the present research lead us towards the development of the investigative approach, including in the line of identifying ways to support a better collaboration between the teacher for primary school education and Religion Education teacher. We especially consider the possibilities of carrying out interdisciplinary activities of project type, especially when the class group includes between the intercultural elements that define it different religious and ethnic components.

\section{References:}

Bocoş, M., Opriş, D., Opriş, M. (2006). Cercetarea în domeniul educaţiei morale şi al educaţiei religioase. Modele şi aplicaţii [Research in the field of moral education and religious education. Models and applications]. Editura Casa Cărţii de Ştiinţă, ClujNapoca.

Cernat, V. (2005). Psihologia stereotipurilor [Psychology of stereotypes]. Editura Polirom, Iaşi.

Ciolan, L. (2000). Paşi către şcoala interculturală - ghid de educaţie interculturală pentru cadrele didactice [Steps to intercultural school - intercultural education guide for teachers]. Editura Corint, București.

Cucoş, C. (2000). Educaţia. Dimensiuni culturale şi interculturale [Education. Cultural and intercultural dimensions]. Editura Polirom, Iaşi.

Gavreliuc, A. (2011). Psihologie interculturală [Intercultural psychology]. Editura Polirom, Iaşi.

Lungu, R., Popeţi, E. (2012). Educaţie interculturală. Pentru copii migranţi în România [Intercultural education. For migrant children in Romania]. Institutul Intercultural Timişoara.

Opriş, D., Opriş, M. (2013). Religia şi educaţia de mâine. Cercetări pedagogice [Religion and education for tomorrow. Pedagogical research]. Editura Eikon, Cluj-Napoca.

Opriş, M., Opriş, D., Bocoş, M. (2004). Cercetarea pedagogică în domeniul educaţiei religioase [Pedagogical research in the area of religious education]. Editura Reîntregirea, Alba Iulia.

Opriş, M., Opriş, D. (2013). Cercetare şi religie. Repere şi demersuri comune [Research and religion. Common guidelines and approaches]. Editura Eikon, Cluj-Napoca. 
Pavalache-Ilie, M., Voinea, M., Unianu, E. M. (2014). Students' perception on the necessity of intercultural education in Romania. Procedia - Social and Behavioral Sciences, 128, pp.447-452.

Plugaru, L., Pavalache M. (2007). Educaţie interculturală [Intercultural education]. Editura Psihomedia, Sibiu.

Spînu, S. (2018). Comunicarea interculturală şi provocările identităţii [Intercultural communication and the challenges of identity]. In: O. Moşin, I. Scheau, D. Opriş (ed.), Educaţia din perspectiva valorilor. [Education from the perspective of value] Tom. XIII, Editura Eikon, Bucureşti, pp.53-58. 